investigación económica, vol. LXIX, 274, octubre-diciembre de 2010, pp. 17-41.

\title{
On the dismal state of a dismal science?
}

Heinz D. Kurz*

\section{Queen AND Would-be Queen}

On the occasion of her visit to the London School of Economics in November 2008, Her Majesty Queen Elizabeth asked the assembled scientific community why the financial crisis had not been anticipated and measures proposed and taken to fight it. On 22 July 2009 two Fellows of the British Academy, Professors Tim Besley and Peter Hennessy, answered the Queen in a letter in which they summarise "the views of the participants and the factors that they cited" on the occasion of a forum the British Academy had convened on 17 June 2009 to debate the questions raised by the Queen (Besley and Hennessy 2009). They point out that while there had been warnings about imbalances in financial markets and in the global economy, what mattered was not "just to predict the nature of the problem but also

Received June 2010; accepted September 2010.

* Department of Economics, University of Graz, and Graz Schumpeter Centre, <heinz.kurz@unigraz.at>. I am grateful to Tony Aspromourgos, Lutz Beinsen, Duncan Foley, Harvey Gram, Geoff Harcourt, Manfred Holler, Neri Salvadori and Hans-Michael Trautwein and two anonymous referees of Investigación Económica for valuable comments on a draft of this paper. The responsibility for the opinions expressed in it is, of course, entirely with me. 
its timing." They admit that only few saw the "risk to the system as a whole" and stress: "But against those who warned, most were convinced that banks knew what they were doing. They believed that the financial wizards had found new and clever ways of managing risks. [...] It is difficult to recall a greater example of wishful thinking combined with hubris." A psychology of denia of the dangers involved is said to have emerged. "It was a cycle fuelled, in significant measure, not by virtue but by delusion." According to Besley and Hennessy, while individual risks and imbalances were perceived, "the failure was to see how collectively this added up to a series of interconnected imbalances over which no single authority had jurisdiction. [...] Individual risks may rightly have been viewed as small, but the risk to the system as a whole was vast." They conclude that "the failure to foresee the timing, extent and severity of the crisis and to head it off [...] was principally a failure of the collective imagination of many bright people [...] to understand the risks to the system as a whole." In short, economists, bankers, financial wizards, politicians and others may be accused of having missed the forest for the trees.

The two Fellows inform the Queen that there are plans to develop in cooperation with other Crown servants "a new, shared horizon-scanning capability so that you [the Queen] never need to ask your question again."

Hope is good for breakfast, but bad for supper, maintained Francis Bacon. Will the Queen never ever have to ask her question again?

This clearly depends to a considerable degree on her majesty the Would-be Queen -the "Queen of the social sciences", that is, as Economics has occasionally been called, at least by some economists-. However, the Would-be Queen is not in good shape right now, not least because she is partly responsible for what happened. The Would-be Queen's shape is actually much worse than the brave two Fellows of the British Academy are inclined to think. The main problem does not seem to be so much the fragmentation of solid knowledge as a consequence of an ever deeper division of labour within the field and the lack of aggregating this knowledge into a comprehensive view of the economic system as a whole, although a problem it surely is. According to a growing number of commentators 
the real problem is the dismal state of influential parts of contemporary mainstream economics, especially macroeconomics and financial economics. More particularly, the reference is to the Rational Expectations School in macroeconomics, championed by Robert Lucas jr., Thomas Sargent and Edward Prescott, and the Efficient Markets Hypothesis in financial theory, championed by Eugene Fama. Since major representatives of the two lines of thought teach at the University of Chicago, we may, for short, also speak of the Chicago School. It is also known as New Classical Economics (NCE). However, as we shall see below (section 5), NCE and the economics of the old classical economists (and their modern interpretators) are radically different in important respects. ${ }^{1}$

\section{CRACKS IN THE MIRROR}

The two fields mentioned were the object of a frontal assault in the cover story of the July $18^{\text {th }} 2009$ issue of The Economist entitled "Modern Economic Theory. Where it went wrong -and how the crisis is changing it-". It prompted Nobel laureate Robert Lucas jr., the spearhead of contemporary Chicago macroeconomics, to reply in a subsequent issue and defend what in no small degree is the product of his own contributions to modern economics. ${ }^{2}$ His reply also showed in a disarming way that he had nothing to say about how the current crisis came about or what has to be done about it. He expressed his unswerving conviction that there was no alternative to developing economic theory along the rational-expectationsrepresentative-agent-efficient-markets and others approach. He dogmatically rejected the view that the failure of economics required a reconsideration of its dominant method and content. Everything was just right or would become right sooner rather than later, provided contemporary mainstream

\footnotetext{
${ }^{1}$ Due to space constraints, in the following I will largely set aside financial theory and focus attention on macro-theory.

${ }^{2}$ While Alfred Nobel funded the prizes named after him, which are awarded by the Royal Swedish Academy, the prize given to economists is awarded by the Swedish Central Bank.
} 
economists were allowed to carry on and eventually reach out also to areas not yet properly covered by them. ${ }^{3}$ As Lucas had contended triumphantly in 2004, the "potential" of the new theory "is getting realized. It has completely succeeded in taking over growth theory, most of public finance, financial economics. Now it's coming in use in macroeconomics with real business cycle theory" (Lucas 2004:23).

Yet after the ball was over, cracks in the mirror could no longer be ignored or defined away. Nobel laureate Paul Krugman is notorious for his frontal attacks on contemporary macroeconomics in the New York Times and elsewhere. Nobel laureate Joseph Stiglitz has repeatedly put forward criticisms of the views and policy recommendations of the Chicago school of economics and the International Monetary Fund. Even former staunch supporters of the free-market doctrine championed by Chicago economists came up with second thoughts on their beliefs. Richard Posner from the University of Chicago Law School published a piece in The New Republic entitled "How I Became a Keynesian" (Posner 2009b). ${ }^{4}$ In it he distances himself from Gregory Mankiw's 1992 claim that after "fifty years of additional progress in economic science, The General Theory is an outdated book. [...] We are in a much better position than Keynes was to figure out how the economy works." Not true! protests Saulus turned Paulus: "We have learned since September [2008] that the present generation of economists has not figured out how the economy works." Posner adds:

The vast majority of them were blindsided by the housing bubble and the ensuing banking crisis; and misjudged the gravity of the economic downturn that resulted; and were perplexed by the inability of orthodox monetary policy administered by the Federal Reserve to prevent such a steep downturn; and could not agree on what,

\footnotetext{
${ }^{3}$ There is reason to presume that Lucas's optimism was not shared by all people who can be expected to regularly consult The Economist. The financial tycoon George Soros, who has long been known for his disenchantment with the state of certain parts of modern economics, has recently donated a considerable amount of money in order to finance the development of a "new economics" and has put this project into the hands of economists who are known for their critical attitude towards orthodox economics.

${ }^{4}$ For a more complete account of Posner's views, see his book A Failure of Capitalism (Posner 2009a).
} 
if anything, the government should do to halt it and put the economy on the road to recovery. [...] Not having believed that what has happened could happen, the profession had not thought carefully about what should be done if it did happen. (Emphasis added.)

He continues: "Baffled by the profession's disarray, I decided I had better read The General Theory. Having done so, I have concluded that, despite its antiquity, it is the best guide we have to the crisis." Ironically, in Posner's view more than seventy years "of additional progress in economic science" has actually led to regress! This view is shared, among others, by Robert Skidelsky, the Keynes biographer and author of Keynes: The Return of the Master (Skidelsky 2009). ${ }^{5}$

It is worth noting that more than twenty years ago Alan S. Blinder had already asked "whether the Keynesian or new classical answers have greater claim to being "scientific", and had concluded: "when Lucas changed the answers given by Keynes, he was mostly turning better answers into worse ones". However, Blinder felt that modern Keynesian economics $-\mathrm{Neo}$ or New Keynesian Economics (NKE), "though far from flawless", was superior both to Keynes and NCE (Blinder 1987:130 and 136).

Not all observers share this view. One of them is Jeffrey Sachs, who passes a particularly humiliating sentence on the macroeconomics mainstream in general in a paper entitled "Rethinking Macroeconomics", published in Capitalism and Society (Sachs 2009):

The financial crisis of 2008 was not an accident. It was the result of a long period of political decadence in the United States aided and abetted by a growing bole in economic science. Decadence is a tough word, but the truth is that the us walked headlong into the fury. Because of the central role of both the dollar and Wall Street in the global financial system, and because of the centrality of Us [United States] economic thinking in shaping global economic policies and institutions, the rest of the world has been carried with it into the fury (Sachs 2009: 1; emphases added). ${ }^{6}$

\footnotetext{
${ }^{5}$ See also Peter Clarke's book on Keynes: the Rise, Fall, and Return of the 20th Century's Most Influential Economist (2009) and the book edited by Bradley Bateman, Toshiaki Hirai and Cristina Marcuzzo on The Return to Keynes (2010).

${ }^{6}$ As Keynes (1936:383) observed: "the ideas of economists and political philosophers, both when they are right and when they are wrong, are more powerful than is generally understood. Indeed the world
} 
According to Sachs, both Neo-Keynesians and free-market economists of various stripes -typically grouped under the rubrics of supply-side, rational-choice, rational-expectations, efficient-market, real-business-cycle theories- are responsible for the dismal performance of what Thomas Carlyle in the second half of the nineteenth century (and with reference to Thomas Robert Malthus's doctrine) had dubbed the "dismal science". Sachs is, of course, aware that NKE and NCE differ in several respects. Yet in his view the differences count for little compared with what is common to them. These concern the belief that global economic policy is not much needed; that the focus should be on price stability, low unemployment and high economic growth; that low marginal tax rates and market liberalisation are invariably a good thing; that the distribution of income and wealth should not be a concern; and that structural issues such as energy, climate, health care and infrastructure are of little macroeconomic significance. These common creeds of the two leading schools, Sachs argues, are well reflected in us macroeconomic policies from the early 1980s until today. He adds: "The collapse of the subprime bubble has given some pause, but the old policy machine is still trying to rise from the rubble, something like a Terminator robot reassembling its parts after a seemingly shattering blow." Yet what is truly needed is "a new strategy of economic governance -one that is structural and global" together with "a new science of macroeconomics" (Sachs 2009:3). However, the prospects for these to come about look bleak. Sachs decries bitterly that

Wall Street is readying to launch the biggest stinkbomb of all, by pocketing the bailout support (including zero-interest credits from the Fed as well as overpayments for toxic assets) in a new round of mega-bonuses for the miscreants who caused the crisis in the first place. Yet Congress and White House are set to let this happen, so as not to cross their campaign financiers in the lead-up to the 2010 elections (Sachs 2009:4-5; emphasis added).

is ruled by little else. Practical men, who believe themselves to be quite exempt from any intellectual influences, are usually the slaves of some defunct economist." As Sachs rightly insists, the influential economists need not be defunct, but can be very much alive and thriving. 
In Sachs's view the main problem is that Wall Street has bought politics and that therefore there is little hope for the much needed fundamental change in economic policy and institutional reforms.

Interestingly, also the main editor of Capitalism and Society, Nobel laureate Edmund Phelps, known as a radical advocate of "free markets", felt the need to rethink his long-standing point of view vis-à-vis the crisis. ${ }^{7}$ In various comments and interviews he distances himself from his previous position and insists that "capitalism would collapse without the state" and that "the financial sector no longer supports firms". 8

Despite all the effort put into becoming, or at least behaving, like a normal science, preferably physics, economics appears to have suffered from a significant loss in reputation both in the academic and in the public domain. Today economics rides the crest of intellectual contempt and popular ridicule. Yet signs of its decline in public appreciation are much older. While in the past a discipline that gave occasion to great hopes as to its capacity to contribute to solving economic and social problems, economics in more recent times has lost much of its former nimbus and is often regarded as barren and irrelevant when it comes to tackling practical problems. Commentators are not much impressed by some of the latest mathematical fads and models in economics and express the view that these

\footnotetext{
${ }^{7}$ It is to be recalled that it was precisely Phelps who, together with Milton Friedman and Robert Lucas, resurrected 'Say's Law' reasoning in macroeconomics. (On the different meanings of Say's Law in classical and neoclassical economics, see section 3 below.) It would be interesting to know what motivates a growing number of prominent leaders of conventional economics (like Posner, Phelps or Sachs) putting forth critiques, and even more so just where they are going with these critiques. The future will tell.

${ }^{8}$ See the interview he gave to the Süddeutsche Zeitung in the Christmas issue of 24-27 December 2009, no. 297, p. 19. The widespread myth that the establishment of the modern capitalist market economy went together with a gradual retrenchment of the state and state intervention since the Industrial Revolution is convincingly refuted by the economic historian Lars Magnusson. He concludes: "It is not a spontaneous order of self-interested individuals which emerge $[\mathrm{s}]$ as a consequence of the abolition or reform of the regulatory system, but rather new forms of governance and regulations which also, so it seems, are better able to do the job of achieving modern economic growth and the establishment of industry. Instead of shrinking in size and importance, we can see a more powerful state emerging during the 19th century." (Magnusson 2009: 145).
} 
models cannot possibly be of much help in understanding the real world and are in all probability highly misleading. Tools are said not to be tailored to the problems tackled, but rather the other way round, with the result that parts of the discipline live mentally in a fool's paradise. In 2005, well before the outbreak of the crisis, Le Monde diplomatique published an article in which scientists assessed the achievements of some of the so-called 'Nobel Prize' winners in economics. The article is significantly entitled: "Prix Nobel d'Économie: L'imposture" (Henderson 2005). From the critics' point of view there is no reason for the representatives of the economic theory under consideration to be self-complacent. ${ }^{\text {? }}$

First soundings of doubts as to the trend economic theory followed during the past few decades can actually be traced back much further and they came from within the discipline. For example, as early as in his 1970 Presidential address to the American Economic Association Wassily Leontief, Nobel laureate 1973, deplored the "uncritical enthusiasm for mathematical formulation [in economics, which] tends often to conceal the ephemeral substantive content of the argument behind the formidable front of algebraic signs". Leontief surmises that "any one capable of learning elementary, or preferably advanced calculus and algebra, and acquiring acquaintance with the specialized terminology of economics can set himself up as a theorist" (Leontief 1971). He vehemently rejected the instrumentalist methodology, advocated by Milton Friedman and then widely adopted in economics, that what matters is not the realism of the assumptions, but the realism of the results derived with its help - the "predictive power" of the theory. ${ }^{10}$ This is

\footnotetext{
${ }^{9}$ The truly interesting question is, how the scholarly standards could have been established that have protected a closed shop in macroeconomics and financial economics over the last few decades. It is to be hoped that a sociology of economics will be elaborated before long that succeeds in identifying the external incentives and internal mechanisms that led to the observed agglomeration of power within the profession.

${ }^{10}$ As Keynes (1936:xxi) had already stressed, the error of orthodox economics "is to be found not in the superstructure, which has been erected with great care for logical consistency, but in a lack of clearness and generality in the premisses." In this context it is perhaps also interesting to note that one of the founders of mathematical and empirical economics, Johann Heinrich von Thünen (17831850), insisted that economics ought to start from realistic assumptions in order not to share the
} 
the only legitimation of the often extremely bold assumptions entertained in much of modern macroeconomic theory, such as the macroeconomic production function, the representative agent, continuous market clearing and others. With the alleged superior power to predict of contemporary macro-theory in a shambles, what now?

\section{WHAT KIND OF 'SCIENCE'?}

Confronted with the apparent massive failure especially of macroeconomics and finance theory one cannot avoid asking the question: What kind of 'science' is economics, assuming, of course, that it is a science? ${ }^{11}$ This question has been vividly discussed since the inception of systematic economic analysis at the time of the classical economists. A particularly famous example is the Methodenstreit between Gustav von Schmoller, head of the younger Historical School in Germany, and Carl Menger, founder of a so-called 'Austrian' school of economics. While Schmoller advocated an inductivist approach, Menger advocated a deductivist one.

The idea that economics should be shaped in the image of the so-called 'hard' or 'exact' sciences, most notably physics, surfaced already at an early time and became predominant in more recent years. Here we need not be concerned with whether the image the scholars advocating this idea have of the natural sciences stands up to close examination or whether it reflects a view that is obsolete by now, as some historians of science maintain. ${ }^{12}$ What matters for the purpose of our argument is that the underlying concept of

\footnotetext{
destiny of the tailors of Laputa in Jonathan Swift's Gulliver's Travels: piling one problematic assumption upon the other landed them right away in Bedlam. On Thünen's respective methodological stance, see Kurz (2009:144-145).

${ }^{11}$ It may be recalled that Nobel laureate Sir John Hicks (1969) had strong doubts that economics should be considered a "science". He felt that it would be better to call it just a "discipline".

${ }^{12}$ See in this context Ilya Prigogine's (2005:69) statement: "In all fields, whether physics, cosmology or economics, we come from a past of conflicting certitudes to a period of questioning, of new openings. This is perhaps one of the characteristics of the period of transition we face at the beginning of this new century." As the statements of economists cited in the above show, the current economic crisis has shaken up the economics profession.
} 
hard science entertained is tantamount to claiming that science is invariably cumulative in the sense that there is progress, progress and only progress; there is never regress. The process of the production and absorption of knowledge is taken to be perfect: whatever is good and valuable will be retained, whereas whatever is weak and erroneous will be dropped. If this were to be true, there could only be an antiquarian interest in the past: Why care about "the wrong ideas of dead men", to use Arthur Cecil Pigou's famous phrase?

But what about the wrong or "irrelevant" ideas of the alive? Should these ideas not also be disposed of? In a nutshell, what is the core belief or "vision" (Schumpeter) of the economic system encountered in NCE? The latter starts from the assumption that rational individuals possessed of rational expectations interact with profitably working competitive firms in perfectly functioning markets. These markets, if left to themselves, are taken to generate efficient economic outcomes. State interference is said to disturb the smooth working of the best mechanism known to create wealth and satisfy needs and wants. State interference is consequently abhorred by advocates of market radical positions, who are at most willing to accept a minimalist state. ${ }^{13}$

But what if the state had not interfered as lender of last resort in order to prevent the economic system from cumulative destabilization during the past two years?

How was it possible that in modern macroeconomics the very possibility of major crises was set aside and actually has become unthinkable? A look at Robert Lucas's work indicates what happened, and why. ${ }^{14}$ As is well known,

\footnotetext{
${ }^{13}$ With regard to Lucas this is not exactly true, as Hans-Michael Trautwein reminded me. On the one hand Lucas contended time and again that Keynesian stabilization policy is bound to be ineffective or inefficient, on the other hand he maintained, somewhat schizophrenically, that the real business cycle hypothesis about the dominance of supply side schocks performs so well because of a successful demand-based stabilization policy in the us in the period after the Second World War (see Lucas 2004:23).

${ }^{14}$ For the following, see also Alan Blinder's pungent criticism of Lucas and defense of Keynes (Blinder 1987) and David Laidler's careful reconstruction of why modern macro-theory developed the way it did (Laidler 2009). See also the paper by Mazzocchi et al. (2009) about what Wicksell and Keynes knew about macroeconomics that many modern economists apparently do no longer know.
} 
one of Lucas's main innovations in macroeconomics was the application of a stripped-down version of intertemporal general equilibrium analysis to traditionally macro questions. In his interpretation this involved simply the use of newly available and superior techniques to deal with received problems which the earlier Keynesian analysis and the related macroeconometrics had been unable to tackle successfully. However, much more was involved than just "progress" in analytical tools. It actually implied a fundamental re-orientation of macroeconomics, its scope and content, breaking with what it was in the 1960s and early 1970s. While originally a theory that focused attention first and foremost on the short period, it now became a long-period theory. In the long period, it was contended, markets, including the labour market, can be expected to work smoothly. Hence the bold assumption, or axiom, was employed that all markets clear at all times and especially that "we have a cleared labor market at every point in time" (Lucas 2004:16). This dispensed with the very problem that once had been the raison d'etre of macro-theory, namely to explain when and why markets and especially the labour market don't clear, and what can be done about it. ${ }^{15}$ Much of modern macro-theory is full employment theory. Rather than reflecting continuity in the scope of macroeconomics, Lucas's move involved a revolution in the sense of the proper meaning of the word: a return to an economics based on 'Say's Law', as it was conceptualised by marginalist (or neoclassical) authors. This conceptualization subsumed the labour market under the 'law of markets' and attempted to deal with it in terms of the usual opposed forces of 'demand' and 'supply', conceived as functions or schedules.

In the original formulation of the law in the classical economists no such subsumption is to be found, nor did these authors put forward the idea of quantitatively definite relationships between the price of a thing and the amount of it demanded or supplied in the market. ${ }^{16}$

\footnotetext{
${ }^{15}$ Blinder (1987:135) put it in the following way: "Must we be restricted to microfoundations that preclude the colossal market failures that created macroeconomics as a subdiscipline?"

${ }^{16}$ It appears to have escaped the attention of most commentators that in the classical economists Say's Law was not taken to apply to what later was called the 'labour market'. As no less an authority than David Ricardo put it in his Principles of 1817: "There is no amount of capital [!] which may not
} 
In the classical authors Say's Law was discussed in terms of the problem whether decisions to save could be expected to entail swiftly decisions to invest of the same magnitude. Income that is not spent, but saved, does not constitute effectual demand and therefore may imply that aggregate effective demand falls short of productive capacity. If and only if investment, which involves a demand for commodities, steps in, can a "general glut of commodities", to use the language employed in a famous controversy between Thomas Robert Malthus and David Ricardo, be avoided. Seen from this perspective, Lucas's approach to macro-theory is based on the assumption that aggregate investment is always equal to full employment savings, that is, that amount of savings that would result in conditions of the full utilization of all productive resources of the economic system. And this is indeed what he assumes. There is no problem of a discrepancy between planned investment and planned savings, and hence there is no problem of aggregate effective demand. Thus, what Lucas takes as a premise was seen as a problem both in classical economics and in Keynes. Obviously, the labour market can clear "at every point in time" only if firms both expect to be able to sell at any point in time what is produced by a fully employed work force and firms are actually able to do so at any point in time. An even casual look at the real world does not support the assumption that "we have a cleared labor market at every point in time". What made Lucas nevertheless think that macro-theory was well advised to proceed in terms of this assumption? It was a further assumption,

be employed in a country, because demand is only limited by production" (Ricardo 1951:290, emphasis added; see also Gehrke and Kurz 2001). Notice that the reference is to the employment of capital, not labour, and to production, not employment. The classical authors envisaged Say's Law to apply to capitalistically produced commodities only. Since labour, although a particular kind of commodity, is not produced and reproduced in a capitalistic way, Say's Law was not applicable. It was only later, in marginalist analysis, that the 'law of markets' was generalized to include a labour market: with flexible prices and sufficient substitutability between goods in consumption and factors in production, all markets, including the markets for factors of production, were taken to clear. Hence the forces of demand and supply were seen to establish a tendency towards the full employment of labour and the full utilization of plant and equipment.

For an in-depth investigation of changes in fundamental concepts from the classical to the marginalist authors, see especially Garegnani (2007) and Kurz and Salvadori (1995:Chapters 1 and 14). 
namely that there is an "auctioneer" who works "very quickly" and does an excellent job, thereby reducing the logic of "any kind of dynamics you like" to that of an economy that is persistently in full employment-full capacity equilibrium (Lucas 2004:23). ${ }^{17}$

Again, it is not a thorough study of the circumstances of success or failure of the coordination of individual actions via a system of interdependent markets in which money is used as a means of exchange and a store of value that supports Lucas's choice of model, but another bold premise. 'Progress' in modern macroeconomics, it seems, advanced to a considerable degree in terms of piling one bold assumption upon the other. This process renders the fictitious world contemplated by the model tractable with the aid of the intertemporal optimizing tools available to the contemporary theorist. By treating the market-clearing and related postulates as axioms rather than as refutable conjectures about how economies might be modelled, Lucas and his followers have sacrificed important substantive issues on the altar of what they consider to be advances in economic techniques. Lucas is admirably clear about what he considers progress in economics to consist of:

I see the progressive $[. .$.$] element in economics as entirely technical: better mathematics,$ better mathematical formulation, better data, better data-processing methods, better statistical methods, better computational methods.

Interestingly, he adds:

I think of all progress in economic thinking, in the kind of basic core of economic theory, as developing entirely as learning how to do what Hume and Smith and Ricardo wanted to do, only better (Lucas 2004:22; emphases added).

\footnotetext{
${ }^{17}$ Here Lucas is overly optimistic or, put differently, he simply assumes that the equilibrium is globally stable. Surely, not "any kind of dynamics" gives the result he wishes to get. Lucas, who tells the reader that he is no mathematician, does not like models that are "too complicated to work them out"; he is particularly critical of "all the dynamics [...] that Samuelson introduced, where anything can happen" and of models that do not lead to clear "predictions" (Lucas 2004:15; emphasis in the original) With the omniscient and omnipotent "auctioneer" Lucas invokes, ex definitione there is no problem of instability and there are clear predictions. Samuelson (1967) has, of course, to be defended against Lucas's criticism that his dynamics allows anything to happen.
} 
This is a remarkable statement for several reasons. First, according to Lucas all progress in economics is "entirely technical", none is substantive and conceptual. Anyone even remotely familiar with economic history on the one hand and the history of economic thought on the other will be surprised by the naivety of this view. It collides with a view expressed by no less an authority than John von Neumann, who insisted in general terms:

As a mathematical discipline travels far from its empirical source, or still more, if it is a second and third generation only indirectly inspired by ideas coming from "reality", it is beset with very grave dangers. It becomes more and more purely aestheticizing, more and more purely l'art pour l'art. This need not be bad if the field is surrounded by correlated subjects, which still have closer empirical connections, or if the discipline is under the influence of men with an exceptionally welldeveloped taste. But there is a grave danger that the subject will develop along the line of least resistance [...] In other words, at a great distance from its empirical source, or after much "abstract" inbreeding, a mathematical subject is in danger of degeneration (Von Neumann [1947] 1961:9; second emphasis added).

The "danger of degeneration", it seems, has not been successfully circumnavigated by important branches of modern macroeconomics. Traveling far from its empirical source has come at a high price. It is up to the reader to decide whether there has also been a lack of "men with an exceptionally well-developed taste".

Second, and closely related: Is the analytical structure and "basic core" of the theories of the classical authors from Hume to Smith and Ricardo really the same as that of intertemporal equilibrium theory of Arrow and Debreu, as Lucas insinuates? Are historians of economic thought that have identified a fundamental cleavage between marginalism and classical economics entirely mistaken? The answer is a clear no. It is beyond the scope of this note to argue this in some detail. Suffice it to refer the reader to the relevant literature and to point out at least one crucial difference between the classical authors and the marginalists. This will be done in section 5 below. Lucas claims authority in a field in which he is not known for having established one. 
The view of progress in economic science Lucas represents has led to the following situation. The current crisis is impossible to understand with the help of modern macroeconomics of the Lucasian variety. In fact, the models which Lucas et al. have elaborated do not even allow us to think about the economic problems that confront us today. Lucas was very well aware of this when at a time when the subprime bubble was in full swing he pointed out that there is a "residue of things" which "the new theories, the theories embedded in general equilibrium dynamics of the sort that we know how to use pretty well now [...] don't let us think about" (Lucas 2004:23). The residue of things he then had in mind were the World Economic Depression in the 1930s, financial crises and their real consequences in Asia and Latin America and the economic depression in Japan since the 1990s. ${ }^{18}$

In view of this admission it comes as a surprise to see Lucas frontally assault Keynes and his followers as unscientific. Let us have a closer look at how Lucas justifies his point of view.

\section{Modern Macro-theory and Keynes}

Whilst Keynes's contribution (Keynes 1936) was regarded highly up until the early 1970s, there has been a remarkable change of opinion thereafter, at least in circles of economists that shaped what was to become the new mainstream. Robert Lucas in a paper triumphantly entitled "The death of Keynesian economics" expressed the radical change that had taken place in the following way:

One cannot find good, under-forty economists who identify themselves or their work as "Keynesian". Indeed, people even take offense if referred to as

\footnotetext{
${ }^{18}$ However, in his Presidential Address delivered at the one-hundred fifteenth meeting of the American Economic Association, January 4, 2003, in Washington, DC, he was less cautious and in fact opined that the "central problem of depression prevention has been solved, for all practical purposes, and has been solved for many decades." He added: "the potential for welfare gains from better long-run, supply-side policies exceeds by far the potential from further improvements in short-run demand management." He concluded with a remark on the progress in macroeconomics: "we are able to form a much sharper quantitative view of the potential of changes in policy to improve peoples' lives than was possible a generation ago." (Lucas 2003:1 and 12; emphasis in the original)
} 
"Keynesians". At research seminars, people don't take Keynesian theorizing seriously anymore; the audience starts to whisper and giggle to one another (Lucas 1980:19; see also Lucas and Sargent 1978).

In Chicago, to be considered a "good, under-forty economist" apparently from the late 1970s onward required almost by definition to be nonKeynesian. Did the people Lucas refers to and who are said not to have taken Keynesian theorizing seriously anymore found their judgment on a thorough knowledge of The General Theory? Or did they form an opinion on it without knowing it? Did Lucas request his graduate students to study Keynes's magnum opus? Or is their whispering and giggling to one another just a sign of an infantile pretension of knowledge? Did Lucas make an effort to prevent his students from becoming uncritical followers of his own doctrine, or is his belittling of Keynes's contribution just an indirect way of promoting his own work and reputation? Does Lucas wish to tell the reader that he has successfully dethroned Keynes as the most important economist of the 20th century?

Actually, in Lucas's view this was not really needed, nor was it possible! According to him "Keynes was no economic scientist", whose contribution is of lasting scientific value, but a "political activist" and ideologue. "Keynes's real contribution", Lucas writes, "[is] not Einstein-level theory, new paradigm, all this." It is "just so much hot air". Keynes was rather "viewing himself as a spokesman for a discredited profession. That's why he doesn't cite anyone [!] but crazies like Hobson." ${ }^{19} \mathrm{He}$ is said to have responded ad hoc to the challenges of the Great Depression, that is, "a situation where people are ready to throw in the towel on capitalism and liberal democracy and go with fascism or corporatism, protectionism, socialist planning." Keynes's remedy was to assign "new responsibilities" to the government in order to stabilize overall spending flows. Lucas admits that this was "a great political

\footnotetext{
${ }^{19}$ Whether Hobson deserves to be called a 'crazy' need not concern us here. It suffices to recall that Keynes cited, among many others, Bentham, Böhm-Bawerk, Cassel, Edgeworth, Irving Fisher, A. Hansen, Harrod, Hawtrey, Hayek, Jevons, Kahn, Kuznets, Marshall, Marx, J.S. Mill, Pigou, D.H. Robertson, Sraffa, Walras, Wicksell. One can only wonder which edition of The General Theory Lucas has read.
} 
achievement", and that the profession of economists should learn from it that "we have to earn our living by helping people diagnose situations that arise and helping them understand what is going on and what can be done about it." Yet Keynes is said to have contributed nothing of lasting substance to "the internal mainstream of economics, that's what we researchers live on". "That was Keynes's whole life", Lucas concludes: "He was a political activist from beginning to end" (Lucas 2004:23-24; emphasis added).

Here Keynes, the political activist and ideologue, there Lucas, the scholar and economic scientist. This portrait borders on ridicule and need not be commented upon. Suffice it to ask once again the rhetorical question how the Lucas type of theorists "[helped] people diagnose situations that arise and [helped] them understand what is going on and what can be done." There is some sad element of truth in Richard Posner's dictum that The General Theory "is the best guide we have to the crisis" right now. It is also ironic to see that both large parts of the mainstream in economics then, that is at the time of the First World Economic Depression, and now was taken by surprise and had nothing substantial to offer to cope with the situation. Contrary to Lucas's opinion, progress in tools and techniques may be of little help in understanding "what is going on", if the wrong tools and techniques are applied. The tools and techniques Lucas employed correspond to the vision of the working of the economic system he entertains. As we have seen, according to him the market economy works smoothly and efficiently. The tools he elaborated were designed to support this vision, which turned out to be untenable.

In this context it is perhaps of some interest to recall what sage Johann Wolfgang von Goethe had to say about theories. He wrote:

Theorien sind gewöhnlich Übereilungen eines ungeduldigen Verstandes, der die Phänomene gern los sein möchte und an ihrer Stelle deswegen Bilder, Begriffe, ja oft nur Worte einschiebt. Man ahnt, man sieht auch wohl, daß es nur ein Behelf ist; liebt sich nicht aber Leidenschaft und Parteigeist jederzeit Behelfe? Und mit Recht, da sie ihrer so sehr bedürfen (Goethe 1953: 440). ${ }^{20}$

\footnotetext{
20 "Theories are commonly outpourings of an impatient mind that would like to get rid of the phenomena and therefore replaces them by images, notions and often merely words. One senses
} 
Passion and faction spirit are indeed driving forces in life and also in the sciences, especially in those that are exposed to what Karl Marx once called 'the furies of private interest'. It is up to the reader to decide which of the two, Lucas or Keynes, was more of an economic scientist or an ideologue and political activist. ${ }^{21}$

To conclude this section, let us recall what a largely unknown economist has to say about the sort of crisis we are in right now and what the main problem is:

Speculators may do no harm as bubbles on a steady stream of enterprise. But the position is serious when enterprise becomes the bubble on a whirlpool of speculation. When the capital development of a country becomes a by-product of the activities of a casino, the job is likely to be ill-done. The measure of success attained by Wall Street, regarded as an institution of which the proper social purpose is to direct new investment into the most profitable channels in terms of future yield, cannot be claimed as one of the outstanding triumphs of laissez-faire capitalism - which is not surprising, if I am right in thinking that the best brains of Wall Street have been in fact directed towards a different object.

He added:

It is usually agreed that casinos should, in the public interest, be inaccessible and expensive. And perhaps the same is true of stock exchanges. ${ }^{22}$

What is needed today is not only a global "lender of last resort", but also a global "regulator", i.e., a world financial system that serves "the proper social purpose" of directing new investment into the most profitable channels.

\footnotetext{
and even sees that this is only a poor substitute; but does not passion and faction spirit always love substitutes? And rightly so, because they are so much in need of them." (The translation is mine.) Harvey Gram reminded me of the fact that Adam Smith expressed a related idea in his essay on "The History of Astronomy" when he argued that the human mind is calmed by seemingly coherent explanations of otherwise mysterious phenomena.

${ }^{21}$ Blinder (1987) is very clear in this respect: Keynes's attitude is considered more scientific than the attitudes of Lucas, Sargent or Prescott. He actually sees "religious zealotry" rather than scientific detachment at work in NCE and deplores an amazing disrespect for facts.

22 The author is, or course, Keynes; see Keynes (1936:159; emphases added).
} 


\section{AN ALternative VieW OF THE MARKET ECONOMY}

There are alternative views of how a market economy works and what the role of prices is. Here I focus attention on the view of the classical economists, as it was revived by Piero Sraffa (1960). A close examination of the doctrines of Adam Smith and Ricardo shows that Lucas's view of them cannot be sustained. In particular, there is no presumption in classical theory that the economic system tends toward the full employment of its productive resources, especially labour. Labour unemployment is rather seen as a normal phenomenon not only in the short, but also in the long run in a competitive economy; see in this context especially Ricardo's discussion of labour displacement due to the introduction and diffusion of improved machinery and other forms of labour saving technical progress. ${ }^{23}$

The foundation of the classical economists' different view of the economic system is reflected in their approach to the theory of relative prices and income distribution. According to Smith and Ricardo, normal or "natural" prices do not perform the task of guiding the economy to full employment. Prices are not scarcity indexes, as in marginalist theory, but reflect the distribution of the product between workers, capital owners and landlords in given institutional conditions. Income distribution is not explained with reference to the demand for and the supply of productive factors, labour, capital and land. Therefore there is also no explanation of distribution in terms of marginal productivities of the respective factors. Profits (and rents) are a residual income that obtains within a given system of production and given real wages (or the share of wages).

\footnotetext{
${ }^{23}$ It ought to be added that neo-Keynesian macro models also allow for persistent unemployment. Blinder (1987:134) had already asked: "What if there is a systematic tendency for output to be too low on average?" He answered: "Then the Keynesian goal of filling troughs without shaving off peaks starts to make sense." However, different from classical economics neo-Keynesian models trace unemployment back to market imperfections and frictions of various kinds that prevent the economy from settling swiftly (ar at all) in a position of full employment; see, for example, most recently Blanchard and Galì (2008). Basically these models share the concept of prices as scarcity indexes, which is not to be found in the classicals, as the following discussion will argue.
} 
With the analysis not constrained by the straightjacket of the full employment assumption, we do not encounter in classical economics such concepts as Pareto optimality: A system which, in normal conditions, exhibits smaller or larger margins of underutilization of its productive capacity and work force is subject to different laws than a system characterized by full employment and full capacity utilization throughout, as contemplated by Lucas and his followers. In the latter effective aggregate demand, by definition, can have no impact on the growth performance of the system, whereas in the former it does have an effect.

A peculiarity of demand-constrained systems is that over longer periods of time the excess capacity does not become fully visible and one can easily fall victim to the illusion that the capital stock is always more or less fully utilized. As regards labour, we are familiar with the phenomenon that the longer workers are without jobs the more difficult it is to reintegrate them into the employment system, because being on the dole is accompanied by a gradual deterioration of skills and the capacity to work. As regards capital, any underutilization implies a smaller social product, therefore a smaller rate of the formation of additional capital, therefore a smaller rate of growth of the social product, etc. Hence, a level of effective demand that falls short of productive capacity during some time is reflected in the short run by an underutilization of capacity and in the long run by forgone opportunities of additional increments of productive capacity to come into existence. While the labour force will be diminished as a consequence of unemployment caused by effective demand failures, the capital stock will grow at a slower pace than feasible. In both cases the full effects of an insufficient effective demand are concealed. The inattentive observer might actually conclude that in the long run the system can be assumed to operate in conditions of close to full employment of labour and close to full capital utilization, whereas what has actually happened was that effective demand has slowed down the development of the supply side of the economy. It is a misconception entertained by supply side economists that the supply side can be studied without taking into account aggregate effective demand. 
In assuming full employment of labour and full capacity utilization, neoclassical models, old and new, follow the example of Solow who in his 1956 contribution explicitly set aside problems of effective demand and assumed what he called a 'tight rope view of economic growth'. This does not mean that there are no such problems, as Solow was to stress time and again and also most recently (see Aghion and Durlauf 2005:5). Despite his warnings, neoclassical growth theorists, including Lucas, continued to be concerned almost exclusively with the evolution of potential output and ignored all effective demand failures. Interestingly, the subject index of the Handbook of Economic Growth just referred to has no entry on capacity or capital utilization. Ignoring the demand side, that is, assuming Say's Law, is justified in terms of the overwhelming importance of long-run growth compared with short-run fluctuations. These authors fall victim to the illusion mentioned above. Assume two identical economies except for the fact that one, due to a better stabilization policy, manages to realize on average, over a succession of booms and slumps, a higher average rate of capacity utilization than the other economy. With $Y$ as actual and $Y^{*}$ as capacity (or potential) output, $s$ as the savings rate, $v$ as the actual and $v^{*}$ as the optimal capital-to-output ratio and $u=Y / Y^{*}$ as the average degree of utilization of productive capacity, we have

$$
g_{i}=\frac{S}{Y} \frac{Y}{K}=\frac{S}{v}=\frac{S}{Y} \frac{Y^{*}}{K} \frac{Y}{Y^{*}}=\frac{s}{v^{*}} u_{i} \quad(i=1,2)
$$

Assume now that $s=0.2$ and $v^{*}=2$, but $u_{1}=0.8$ and $u_{2}=0.7$. Then the first economy would grow at eight per cent per year, whereas the second would grow at only seven per cent. This may seem a trifling matter, and in the short run it surely is, but according to the compound (instantaneous) interest formula after about 70 years the first economy would be larger than the second one by the amount of their (common) size at the beginning of our consideration. Hence effective demand matters. Experience also suggests that there is no reason to presume that actual savings can be 
expected to move sufficiently close around full employment and full capacity savings. Persistently high rates of unemployment in many countries, both developed and less developed, strongly indicate that the problems of growth and development cannot adequately be dealt with in terms of the full employment assumption.

There are several further results derived within the framework of the classical theory of value and distribution which undermine the Chicago school approach to macro-theory. One is, of course, that there is no macro production function which could be derived from micro units. Hence the production part underlying the approach cannot be sustained and lacks micro foundations. Also the representative agent is without any support from micro theory. ${ }^{24}$ The phenomena of the reswitching of techniques and of reverse capital deepening imply that the relationship between capital per unit of labour and the rate of profits is increasing. The negative implication for traditional theory is close at hand (see Kurz and Salvadori 1998). In terms of the usual diagram meant to depict the capital market: with the supply curve (or correspondence) of capital taken as a parallel to the ordinate (giving the rate of profits), the demand curve is upward sloping. Equilibrium will be given by the intersection of the two curves; it is unique, but unstable. With perfect competition, conceived of (as in neoclassical theory) as including the perfect flexibility of the distributive variables, a deviation of the actual from the equilibrium rate of profits would lead to the absurd conclusion that one of the two income categories, wages and profits, would disappear. This is not what can be observed in the real world.

\footnotetext{
${ }^{24}$ It is not clear whether Lucas (2004:20) wanted to provide some justification for the representative agent when contending that Hume, Smith and Ricardo took people "as basically alike, pursuing simple goals in a pretty direct way, given their preferences". He continues: "We got that view from Smith and Ricardo, and there have never been any new paradigms or paradigm changes or shifts." He hastens to add that he does not want to say "that everything is in Smith and Ricardo" (21), because, as we have heard in the above, there is progress in economics - "better mathematics, [...]" While he never defines what he means by the theory of the classical economists, it appears to be safe to assume that he identifies it with "supply and demand, people maximizing, markets" (see Lucas 2004:15).
} 


\section{CONCLUDING REMARK}

The principle of effective demand (Keynes) matters, in the long run no less than in the short run. Economics may be a dismal science or discipline, but its present dismal state applies not to the discipline as a whole or to all traditions of economic thought available. It applies to the neoclassical mainstream and especially to NCE. It does not apply to some other lines of economic thought, which, to the detriment of the discipline and also to the detriment of society, have been marginalized in the recent past. Severe economic crises request the economics profession to reconsider its doctrines, abandon views that can no longer be sustained, return to views that can, or create new ones appropriate to the current situation. As Keynes put it succinctly in the Tract on Monetary Reform: "Economists set themselves too easy, to useless a task if in tempestuous seasons they can only tell us that when the storm is long past the ocean is flat again."

\section{REFERENCES}

Aghion, P. and S.N. Durlauf, Handbook of Economic Growth, Two volumes, Amsterdam, Elsevier, 2005.

Bateman, B.; T. Hirai and C. Marcuzzo, The Return to Keynes, Cambridge, Massachusetts, and London, The Belknap Press of Harvard University Press, 2010.

Besley, T. and P. Hennessy, "Letter to Her Majesty The Queen of 22 July 2009", United Kindgom, British Academy, 2009.

Blanchard, O. and J. Galì, "A new Keynesian model with unemployment", National Bureau of Economic Research (NBER) Working Papers, 2008.

Blinder, A.S., "Keynes, Lucas, and scientific progress", American Economic Review, vol. 77(2), 1987, pp. 130-136.

Clarke, P., Keynes: the Rise, Fall, and Return of the 20th Century's Most Influential Economist, New York, Bloomsbury, 2009.

Garegnani, P., "Professor Samuelson on Sraffa and the Classical economists", The European Journal of the History of Economic Thought, vol. 14(2), 2007, pp. 181-242. Gehrke, C. and H.D. Kurz, "Say and Ricardo on value and distribution", The European Journal of the History of Economic Thought, no. 8, 2001, pp. 449-486. 
Goethe, J.-W. von, Schriften zur Kunst, Schriften zur Literatur, vol. 12 of the Hamburg Edition, Hamburg, Christian Wegner, 1953.

Henderson, H., "Prix Nobel d'Économie: L'imposture", Le Monde diplomatique, 2005. Hicks, J.R., A Theory of Economic History, Oxford, Clarendon Press, 1969.

Keynes, J.M., The General Theory of Employment, Interest and Money, London, Macmillan, 1936. Reprinted in D. Moggridge (ed.), The Collected Writings of John Maynard Keynes, vol. VII, London, Macmillan, 1973.

Kurz, H.D., "Johann Heinrich von Thünen", in H.D. Kurz (ed.), Klassiker des ökonomischen Denkens, vol. 1, Munich, Beck, 2009, pp. 140-58.

Kurz, H. D. and N. Salvadori, Theory of Production, Cambridge, Cambridge University Press, 1995.

, Reverse capital deepening and the numéraire, Review of Political Economy, vol. 10(4), 1998, pp. 415-26.

Laidler, D., "Lucas, Keynes, and the crisis", unpublished paper, The University of Western Ontario, London, Ontario, 2009. To be published in Journal of the History of Economic Thought.

Leontief, W., "Theoretical assumptions and non-observed facts", American Economic Review, no. 61, 1971.

Lucas, R.E., "The death of Keynesian economics", in Issues and Ideas, Chicago, University of Chicago Press, 1980.

__. "Macroeconomic priorities", American Economic Review, vol. 93(1), 2003, pp. 1-14.

- "My Keynesian education", in M. de Vroey and K. Hoover (eds.), The IS-LM Model: Its Rise, Fall and Strange Persistence, Annual Supplement to vol. 36 of History of Political Economy, Durham, Duke University Press, 2004.

Lucas, R.E. and T.J. Sargent, "After Keynesian macroeconomics", reprinted in R.E. Lucas and T.J. Sargent (eds.), Rational Expectations and Econometric Practice, London, George Allen and Unwin, 1978.

Magnusson, L., Nation, State and the Industrial Revolution. The Visible Hand, London, Routledge, 2009.

Mazzocchi, R.; R. Tamborini and H.-M. Trautwein, "The two triangles: what did Wicksell and Keynes know about macroeconomics that modern economists do not (consider)?", University of Trento Discussion Papers no. 6, 2009.

Neumann, J. von, "The Mathematician", in R.B. Heywood (ed.), The Works of the Mind, Chicago, University of Chicago Press, 1947, pp. 180-196. Reprinted in A.H. Taub (ed.), John von Neumann. Collected Works, vol. 1, Logic, Theory of Sets and Quantum Mechanics, Oxford, Pergamon 1961, pp. 1-9. 
Posner, R., A Failure of Capitalism. The Crisis of '08 and the Descent into Depression, Cambridge, Massachusetts, and London, Harvard University Press, 2009a.

_- "How I became a Keynesian. Second thoughts in the middle of a crisis", The New Republic, September 23, 2009b.

Prigogine, I., The rediscovery of value and the opening of economics, in K. Dopfer (ed.), The Evolutionary Foundations of Economics, Cambridge, Cambridge University Press, 2005, pp. 61-69.

Ricardo, D., The Works and Correspondence of David Ricardo. Edited and introduced by Piero Sraffa with the collaboration of Maurice H. Dobb, volume I: On the Principles of Political Economy, and Taxation, Cambridge, Cambridge University Press, 1951.

Sachs, J.D., "Rethinking macroeconomics", Capitalism and Society, vol. 4(3), 2009.

Samuelson, P.A., "Indeterminacy of development in a heterogeneous-capital model with constant saving propensity", in K. Shell (ed.), Essays on the Theory of Optimal Economic Growth, Cambridge, Massachusetts, The MIT Press, 1967, pp. 219-231.

Skidelsky, R., Keynes: The Return of the Master, New York, Public Affairs, 2009.

Sraffa, P., Production of Commodities by Means of Commodities. Prelude to a Critique of Economic Theory, Cambridge, Cambridge University Press, 1960. 
